\title{
МЕХАНІЗМИ МАСОПЕРЕНОСУ ІНДІЮ В СdТе ПРИ ДІЇ НАНОСЕКУНДНИХ ЛАЗЕРНИХ ІМПУЛЬСІВ
}

\author{
А. БАЙДУЛАЄВА, ${ }^{1}$ В.П. ВЕЛЕЩУК, ${ }^{1}$ O.І. ВЛАСЕНКО ${ }^{1}$ В.А. ГНАТЮК, ${ }^{1}$ \\ Б.К. ДАУЛЕТМУРАТОВ, ${ }^{1}$ C.М. ЛЕВИЦЬКИЙ, ${ }^{1}$ Т. АОКІ ${ }^{2}$ \\ ${ }^{1}$ Інститут фізики напівпровідників ім. В.Є.Лашкарьова НАН України \\ (Просn. Науки 41, Kü̈в 03028; e-mail: vvvit@ukr. net) \\ УДК 536.331, 539.219.3, \\ ${ }^{2}$ Research Institute of Electronics, Shizuoka University \\ 539.388 .2 \\ (3-5-1 Johoku, Hamamatsu 432-8011, Japan) \\ (c) 2011
}

Розглянуто механізми імпульсного лазерного твердофазного легування CdTe індієм при створенні діодних структур для детекторів рентгенівського і гамма-випромінювання. Показано, що масоперенос індію в CdTe при наносекундному лазерному опроміненні структури In-CdTe до порога плавлення CdTe відбувається за механізмом бародифузї - внаслідок значного градієнта напружень. Розраховано коефіцієнти масопереносу індію та оцінено середню дрейфову швидкість переміщення атомів In в CdTe під час опромінення наносекундним імпульсом ексимерного лазера структури In-CdTe з товщиною плівки In 30 нм при оптимальному для легування значенні густини енергії $E=100 \mathrm{м} Д ж / \mathrm{cm}^{2}$.

\section{1. Вступ}

На даний час явище високої рухливості атомів у кристалах при імпульсному лазерному опроміненні (ІЛО) має велике прикладне значення для твердофазного легування CdTe шляхом опромінення імпульсами лазера структури метал-CdTe у зв'язку з ефективністю, технологічністю, відтворюваністю та зручністю у виборі параметрів під час виготовлення детекторів, чутливих до рентгенівського та гаммавипромінювання з низьким рівнем шумів і високими спектрометричними характеристиками на основі діодів з різким $p-n$-переходом на малій глибині $[1,2]$.

Водночас, механізми процесу масопереносу у структурах плівка металу-напівпровідник при ІЛО на сьогодні з'ясовані недостатньо, у першу чергу, для прогнозування та контрольованої зміни електричних i фотоелектричних характеристик напівпровідникових структур з $p-n$-переходом та омічними і випрямляючими контактами [1-8], особливо на основі $\mathrm{CdTe}$, які використовуються для детекторів іонізуючого випромінювання $[1,2]$. 3'ясування та аналіз механізмів масопереносу необхідно для визначення оптимальних режимів наносекундного лазерного твердофазно- го легування CdTe індієм та аналогічних структур плівка металу-напівпровідник.

Складність механізмів масопереносу при наносекундному ІЛО зумовлена нестаціонарністю, нерівноважністю, фізичною та геометричною нелінійністю, високою швидкістю і одночасністю протікання різних фізичних процесів; зокрема, це зміна агрегатного стану твердого тіла, генерація пружних та ударних хвиль, значних градієнтів температур і напружень, дефектоутворення, дифузія та ін.

Метою даної роботи було встановлення та аналіз домінуючих механізмів масопереносу індію в $\mathrm{CdTe}$ при наносекундному лазерному опроміненні структури In-CdTe.

\section{2. Експеримент}

Проведемо аналіз концентраційного профілю атомів індію в монокристалі CdTе орієнтації (111) після однократного опромінення структури In-CdTe з боку плівки індію товщиною 30 нм імпульсом ексимерного $\left(\lambda=0,248\right.$ мкм) лазера тривалістю $\tau_{p}=20$ нс при густині енергії $E=100$ мДж/см² (рис. 1), який було отримано нами раніше і представлено у роботі [1]. Профіль знімався за допомогою оже-електронної спектроскопії після пошарового травлення пучком іонів аргону. Подібні профілі розподілу домішки в $\mathrm{CdTe}$ при ІЛО отримано в деяких інших роботах $[5,6]$.

3 рис. 1, крива 1, видно, що глибина проникнення атомів індію In у кристал досягає 60 нм від поверхні $\mathrm{CdTe}$, при цьому спостерігається характерний пік на глибині $x=6$ нм, що пояснюється наявністю спрямованого потоку атомів углиб кристала вздовж $x$ із середньою дрейфовою швидкістю $\left\langle v_{x}\right\rangle$ [8-12]; наявність максимуму носить пороговий характер - максимум формується при $\left\langle v_{x}\right\rangle^{2} t>2 D$ (1) [10-12], де $D$ - коефіцієнт масопереносу, a $t$ - сумарний час дії лазерного 


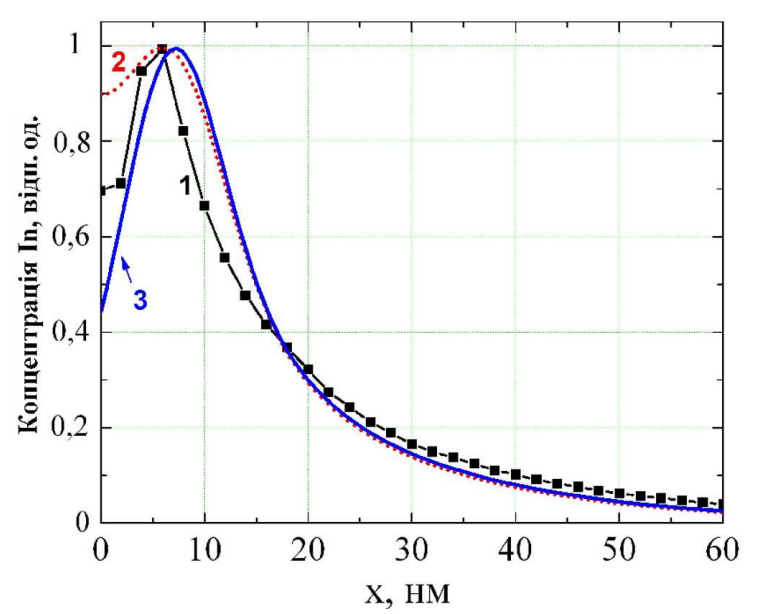

Рис. 1. Концентраційний профіль атомів індію в монокристалі CdTe: експеримент (1) та апроксимація 4-ма експонентами за формулами (1) (крива 2) і (2) (крива 3)

випромінювання, випаровування частини плівки та релаксації градієнта температури та термопружних напружень у дифузійній зоні; $t=100$ нс визначено $з$ температурного профілю In-CdTe при опроміненні i є часом інтенсивного масопереносу або часом існування сил за рахунок градієнтів температури та напружень. Після 100 нс процеси масопереносу практично заморожені і носять релаксаційний характер.

Оскільки в нашому випадку при ІЛО відбувається випаровування тонкої плівки In, можна використати модель дифузії з нескінченно тонкого шару, і концентраційний профіль з урахуванням кінетики процесу проникнення атомів In в CdTe при $C(x, 0)=C_{0} \delta(x)$ по глибині може бути описаний виразами з роботи [12]:

$$
\begin{aligned}
& C(x, t)=\frac{C_{0}}{2 \sqrt{\pi D t}}\left[\exp \left(-\frac{\left(x-\left\langle v_{x}\right\rangle t\right)^{2}}{4 D t}\right)+\right. \\
& \left.+\exp \left(-\frac{\left(x+\left\langle v_{x}\right\rangle t\right)^{2}}{4 D t}\right)\right]
\end{aligned}
$$

або з роботи [10]:

$$
\begin{aligned}
& C(x, t)=\frac{C_{0}}{2 \sqrt{\pi D t}} \exp \left(-\frac{\left(x-\left\langle v_{x}\right\rangle t\right)^{2}}{4 D t}\right)- \\
& -\frac{C_{0}\left\langle v_{x}\right\rangle}{4 D} \exp \left(\frac{\left\langle v_{x}\right\rangle x}{D}\right) \operatorname{erfc}\left(\frac{x+\left\langle v_{x}\right\rangle t}{2 \sqrt{D t}}\right),
\end{aligned}
$$

де $C_{0}$ початкова концентрація атомів In на поверхні $(x=0), \delta(x)$ - дельта-функція.

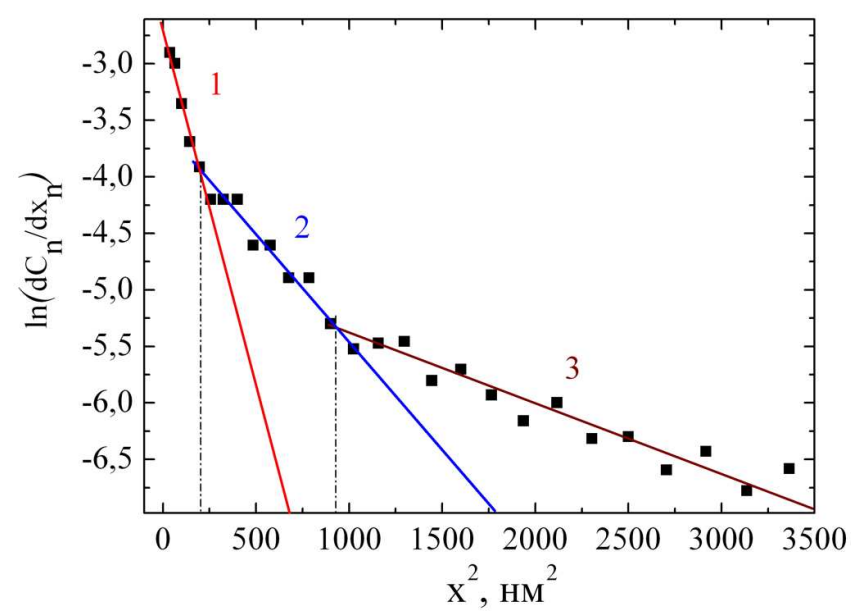

Рис. 2. Лінеаризоване представлення концентраційного профілю атомів індію в $\mathrm{CdTe,} \mathrm{виходячи} \mathrm{із} \mathrm{рис.} 1$

У даному випадку при описі масопереносу при ІЛО можна використати формалізм Маннінга про наявність та істотний вплив на масоперенос рушійної сили, що спричиняе спрямований потік атомів зі швидкістю $\left\langle v_{x}\right\rangle$ [9-11]. Коефіцієнт масопереносу $D$ визначався за виразом $D=(4 t \operatorname{tg} \alpha)^{-1}$, де $\alpha \in$ кутом нахилу кривої $\ln \left(\Delta C_{n} / \Delta x_{n}\right)=f\left(x_{n}^{2}\right)$, перебудованої із залежності концентраційного профілю атомів In в $\mathrm{CdTe}$ на рис. 1, крива 1 графічним диференціюванням за методикою [12-14].

На рис. 2 наведено розподіл атомів індію в CdTe y координатах $\ln \left(\Delta C_{n} / \Delta x_{n}\right)-x^{2}$ для лінеаризації кривої, зображеної на рис. 1 , від $x=6$ нм, оскільки концентрація індію знижується приблизно за експонентами відповідно до виразів (1) і (2). На даному розподілі виділяються три характерні лінійні ділянки, для яких коефіцієнт масопереносу In в CdTе при IЛО дорівнює: $1-D_{1}=3,9 \cdot 10^{-6} \mathrm{~cm}^{2} / \mathrm{c} ; 2-D_{2}=1,46 \cdot 10^{-5}$ $\mathrm{cm}^{2} / \mathrm{c} ; 3-D_{3}=5,2 \cdot 10^{-5} \mathrm{~cm}^{2} / \mathrm{c}$.

3 рис. 2 видно, що коефіцієнт масопереносу зростає із глибиною і в приповерхневому шарі (до 14 нм) менший, ніж в об'ємі кристала. Такі ж ділянки з різними $D$ або злами на розподілі дифундуючих елементів (радіоактивних ізотопів металів) спостерігалися в різних металах (Fe, Mo, Nb, Ti, Al) після їх деформації імпульсним механічним навантаженням шляхом удару зі швидкістю відносної деформації від 1 до $100 \mathrm{c}^{-1}$ при підвищених температурах [16], а також у [10, 15] в умовах зовнішніх імпульсних впливів.

Лінійні ділянки на рис. 2 вказують на об'ємний характер процесу масопереносу на відміну від дифузії по границях зерен і субзерен. У нашому випадку монокристал $\mathrm{CdTe}$ вирощений за технологією низько- 
температурного синтезу, і полікристалічна структура практично була відсутня, при цьому густина дислокацій була не більша $\rho_{\text {disl }} \approx 10^{4} \mathrm{~cm}^{-2}$.

Оскільки на лінеаризованому концентраційному профілі є три злами, які відповідають 3-м експонентам, весь експериментальний профіль можна апроксимувати 4-ма експонентами. Четверта експонента відповідає дифузії в області піка (на ділянці від 0 до 10 нм) з іншим коефіцієнтом дифузії $D_{0}$, меншим від $D_{1}$ на величину $n=D_{3} / D_{2} \ldots D_{2} / D_{1}$. На рис. 1 крива 2 відповідає апроксимації 4-ма експонентами за формулою (1), крива 3 - за формулою (2), 3 такими параметрами: $D_{0}=1,1 \cdot 10^{-6} \mathrm{~cm}^{2} / \mathrm{c}, D_{1}=3,9 \cdot 10^{-6}$ $\mathrm{cm}^{2} / \mathrm{c} ; D_{2}=1,46 \cdot 10^{-5} \mathrm{~cm}^{2} / \mathrm{c} ; D_{3}=5,2 \cdot 10^{-5} \mathrm{~cm}^{2} / \mathrm{c}$, $\left\langle v_{x}\right\rangle=6 \mathrm{~cm} / \mathrm{c}$. Розрахунок швидкості буде наведено нижче. Така апроксимація добре описує експериментальний профіль індію. Відзначимо, що для врахування впливу зміни розмірів зразка у процесі деформування, для коефіцієнта $D$ вводиться поправка (множник) $a=2 \varepsilon_{\max } /\left(e^{2 \varepsilon_{\max }}-1\right)$, де $\varepsilon_{\max }-$ деформація $[10,14,15]$. Проте в нашому випадку $а$ не менше за 0,9 , а $D_{0}, D_{1} \ldots D_{3}$ відрізняються в 3,7 раза.

На масоперенос In в CdTe при IЛО ексимерним [1] або рубіновим [7] лазером (наносекундному лазерному твердофазному легуванні) вказують зміни ВАХ. На рис. 3 представлено BAX In-CdTe-Au структури у вихідному стані (крива 1) та після однократного опромінення (криві 2 і 3) з боку індію товщиною 400 нм ексимерним лазером в атмосфері аргону при тиску 3 атм. Вигляд ВАХ після опромінення свідчить про посилення випрямляючих властивостей структури за рахунок легування приповерхневого шару CdTe індієм і утворення $p-n$-переходу, як і в [1]. Густина струму витоку при зворотному зміщенні 100 В зменшилась з $900 \mathrm{HA} / \mathrm{cm}^{2}$ (рис. 3, крива 1) до $135 \mathrm{HA} / \mathrm{cm}^{2}$ (крива 2) та до 45 нА $/ \mathrm{cm}^{2}$ (крива 3). Відповідно понизиться і рівень шумів такої детекторної структури.

\section{3. Особливості масопереносу In в CdTe. Баро- i термодифузія}

Дифузія індію в СdТе при ІЛО відбувається в умовах значних градієнтів температури та термопружних (i пластичних) напружень при сильно неоднорідному нагріві по глибині.

Відповідно до наших розрахунків, при IЛО структури з густиною енергї $E=50-400 \mathrm{м} Д ж / \mathrm{cm}^{2}$ та коефіцієнті оптичного відбиття індію $R=0,8$ швидкості наростання та градієнти температури і тиску по глибині досягають значень: $d T / d t=6 \cdot 10^{9}-5 \cdot 10^{10}$

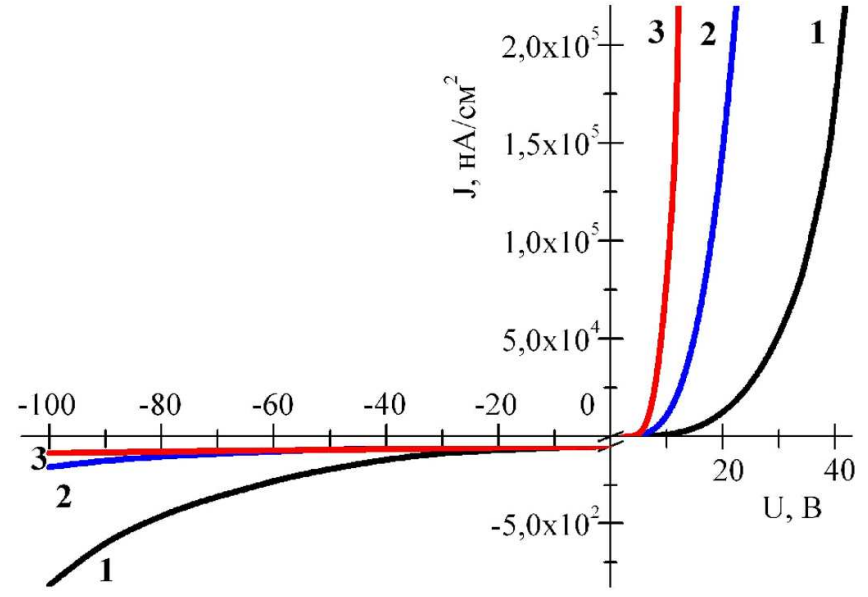

Рис. 3. ВАХ структури In-CdTe-Au до (крива 1) та після (криві 2 і 3) опромінення наносекундними імпульсами ексимерного

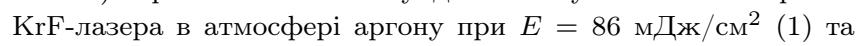
$E=108$ мДж/ $\mathrm{cm}^{2}(2) . T=300 \mathrm{~K}$

град/c, $d T / d x=10^{8}-10^{9}$ град/м, $d P / d t=4 \cdot 10^{15}-10^{16}$ $\Pi \mathrm{a} / \mathrm{c}, d P / d x=3 \cdot 10^{13}-3,6 \cdot 10^{14} \Pi \mathrm{a} / \mathrm{м}$.

Поздовжній градієнт тиску у твердій фазі при ІЛО $\frac{d P}{d x}=\alpha_{T}(T) E \frac{d T}{d x}$ розраховано як з урахуванням температурних профілів для обчислення $d T / d x$, так і тиску $P$ на поверхні. Тут $E$ - модуль Юнга, $\alpha_{T}(T)$ - коефіцієнт лінійного термічного розширення. Під дією механічної сили $[8,17]$ :

$F_{P}=\frac{4}{3} \frac{1-\nu^{2}}{(1-2 \nu)^{2}} G\left(\Omega_{i}-\Omega_{0}\right) \nabla\left(\alpha_{T} T\right)$

відбувається дифузія атомів індію за рахунок різниці ковалентних радіусів (дилатаційних об'ємів) домішки In та Cd або Те, або бародифузія. Під дією термічної сили $[8,17]$ :

$F_{T}=-\frac{1}{3} \Omega_{0} C\left\langle\sigma_{0} / \sigma_{i}\right\rangle \nabla T$

відбувається термодифузія за рахунок фононного захоплення атомів домішки, коли атоми домішки переносяться з гарячих місць у холодні. Тут $\nu$ - коефіцієнт Пуасона, $G$ - модуль зсуву, $\Omega_{0}$ та $\Omega_{i}$ елементарні об'єми атомів основної речовини і домішки відповідно, $C$ - теплоємність, $\left\langle\sigma_{0} / \sigma_{i}\right\rangle$ - усереднене відношення перетинів розсіяння фононів атомами основної речовини та домішки відповідно. Сили за рахунок градієнта пружних напружень $F_{P}$ і температури $F_{T}$ спричиняють перенос атомів індію із дрейфовою швидкістю $[8,17]$ :

$v=D\left(F_{P}+F_{T}\right) / k T$. 
Ковалентні радіуси атомів In - 1,44 А, кадмію $1,48 \AA$, телуру - 1,32 А. За рахунок різниці дилатаційних об'ємів за механізмом бародифузії індій буде дифундувати углиб $\mathrm{CdTe,} \mathrm{заміщаючи} \mathrm{Те}\left(\Omega_{0}<\Omega_{i}\right)$, також атоми In по вакансіях $\mathrm{Cd}$ будуть захоплюватись пружною хвилею, оскільки встановлено [1], що інверсія з $p$-типу провідності на $n$-тип відбувається за рахунок заняття атомами In вакансій кадмію. Можливий також випадок заміщення індієм атомів Cd $\left(\Omega_{0}>\Omega_{i}\right)$, але цей потік буде спрямований до поверхні CdTe. Таким чином, у загальному випадку може існувати два протилежно спрямованих потоки атомів In, що і враховано у виразі (1) (два доданки).

У нашому випадку за модулем сила $\left|F_{P}\right|$ більша, ніж $\left|F_{T}\right|$ в $(1,5-7,1) \cdot 10^{3}$ раза. Тому домінуючим механізмом масопереносу є перенесення атомів під дією механічної сили $F_{P}$ або механізм бародифузії під дією значного градієнта $d P / d x,\left\langle\sigma_{0} / \sigma_{i}\right\rangle$ близько $1[18$, 19]. Оскільки $F_{P}$ більша за $F_{T}$, то напрямок потоку залежить від знака різниці $\Omega_{i}-\Omega_{0}$. Величина $v \sim \nabla\left(\alpha_{T} T\right)$, тому в області найбільших величин $\nabla\left(\alpha_{T} T\right)$ швидкість руху атомів індію максимальна. Розрахунок швидкості атомів індію в полі термопружних напружень за формулою (5) з урахуванням експериментально розрахованого $D$ дає діапазон значень $v \approx 0,2-2,6 \mathrm{~cm} / \mathrm{c}$ (дифузія за атомами Те при $\left.D=3,9 \cdot 10^{-6} \mathrm{~cm}^{2} / \mathrm{c}-5,2 \cdot 10^{-5} \mathrm{~cm}^{2} / \mathrm{c}\right)$.

В умовах високоенергетичної дії при наносекундному опроміненні у кристал "закачується" енергія, що акумулюється у вигляді збуджених станів міжвузловинні атоми (МА)-вакансії, потім енергія вивільняється у вигляді потоків МА, вакансій та атомів у полі термопружних напружень. При ІЛО дифузія відбувається, переважно, за міжвузловинним механізмом $[10,15]$.

При перевищенні енергії дифундуючого атома висоти потенціальних бар'єрів атомів гратки або при перевищенні енергії активації руху $\Delta E$, МА буде безактиваційно переноситись в полі пружної хвилі, відбувається його "захоплення" [20]. При перевищенні $\Delta E$ енергї теплових коливань $(k T)$ механізм масопереносу визначається недифузійною природою [15]. Проте в цьому випадку градієнт тиску $d P / d x$ у пружному імпульсі повинен досягати $5 \cdot 10^{18}$ Па/м [20, 21]. Тому розраховані вище градієнти напружень недостатні для здійснення повністю безактиваційного руху атомів In, зокрема MA, але все-таки великі і достатні для їх швидкого термоактиваційного руху в напрямку дії силового пружного поля з дрейфовою швидкістю $v=D F_{P} / k T$. Отже, атоми та MA In переміщую- ться по СdТе шляхом термофлуктуаційних перескоків під дією рушійної сили $F_{P}$.

Середню швидкість спрямованого переміщення атомів індію в CdTе оцінимо також з експериментального профілю (рис. 1). Врахуємо одночасність процесів випаровування поверхні плівки та масопереносу приблизну довжину переносу атомів індію візьмемо від 6 до 15 нм + 6 нм, це сума половини товщини плівки індію та відстані до піка на рис. 1, де концентрація атомів In максимальна та зумовлена їх переносом зі швидкістю $\left\langle v_{x}\right\rangle$. Тоді $\left\langle v_{x}\right\rangle=(6-21 \mathrm{нм}) / 100 \mathrm{нс}=6-21$ см/с, при цьому критерій (1) з урахуванням коефіцієнта масопереносу індію в CdTе в області піка на рис. 1 виконується. Дана величина швидкості атомів індію в CdTe за порядком величини збігається зі швидкістю іонів Zn у $p$ - $n$-переході GaAsP-структур (14 cм/c) при їх переміщенні за рахунок градієнта термопружних напружень при наносекундному ІЛО [17], а також збігається із середньою швидкістю руху атомів $\left\langle v_{x}\right\rangle \approx 13 \mathrm{~cm} /$ с у приповерхневому шарі металів при ix наносекундному ІЛО [12]. Теоретично максимальна величина швидкості руху домішкових атомів $\mathrm{Cu}$ в GaAs при ІЛО досягає $v=180 \mathrm{~cm} / \mathrm{c}$ [8]. Там же показано, що максимум у розподілі за швидкостями атомів домішки відповідає максимальному значенню термопружних напружень та градієнту температури.

Швидкість руху частинок матеріалу (швидкість грані при стиску) у найпростішій задачі про удар при раптовому прикладенні постійної стискаючої сили до тіла з урахуванням його неперервно розподілених деформаційних та інерційних властивостей можна також оцінити за формулою $v=\sigma / \sqrt{\rho E}[22]$. Тут $\rho-$ густина, $\sigma$ - нормальне напруження по перетину, i при $\sigma=2,15 \mathrm{MПа} \mathrm{-} \mathrm{межа} \mathrm{міцності} \mathrm{при} \mathrm{стиску} \mathrm{In,}$ $v=24 \mathrm{~cm} / \mathrm{c}$.

Як було відзначено, нами виявлено факт збільшення коефіцієнта масопереносу атомів In в CdTe із глибиною при ІЛО. Таке ж зростання із глибиною величини $D$ спостерігалося на лінеаризованому розподілі радіоактивних ізотопів металів у різних металах після їх деформації імпульсним механічним навантаженням [16]. Там же і в роботах $[10,11,15]$ спостерігаються злами на лінеаризованих концентраційних розподілах за рахунок різниці рухливості атомів на різних глибинах, при цьому розподіл деформації в дифузійній зоні також нерівномірний. Крім того, у [8] шляхом розрахунку показано зростання із глибиною (i з часом у процесі масопереносу) швидкості дифундуючих атомів при ІЛО. Це вказує на залежність коефіцієнта масопереносу дифундуючих атомів від відстані від поверхні за імпульсного впливу. 
Збільшення коефіцієнта дифузї з відстанню можна пояснити таким чином. Оскільки початок руху атомів та генерація хвилі стиску відбуваються практично одночасно (синхронно), то дифундуючі атоми та імпульс деформації спочатку поширюються разом (атоми в стиснутій гратці, $D_{0}$ ). Потім хвиля стиску за рахунок більшої швидкості поширення поступово йде вперед $\left(D_{1}\right)$ й атоми вже рухаються в менш деформованій гратці $\left(D_{2}\right)$ і далі у ще менш деформованій $\left(D_{3}\right)$. Більше того, задня частина деформаційної хвилі є деформацією розтягу, оскільки згідно з [8] при IЛО напівпровідника на розподілі термопружних напружень у приповерхньому шарі відбувається зміна знака пружних напружень, що відповідає наявності поряд з областю стиску області розтягу. Тому по мірі руху атоми в іншій (глибшій) ділянці кристала будуть перебувати вже в менш стиснутій гратці, відповідно їх коефіцієнт дифузії зростає за рахунок зміни множника $D_{a}$ в коефіцієнті дифузії та величини $E_{\text {act }}-D=D_{a} \exp \left(-E_{\text {act }} / k T\right)$, де $D_{a}=a^{2} / \tau_{0}, a$ - стала гратки, $\tau_{0} \sim 10^{-13}$ с - час порядку періоду коливань атомів кристалічної гратки (відповідає частоті акустичного спектра). Отже, фактично атоми переміщуються у гратці зі змінною деформацією, відповідно їх коефіцієнт дифузї по мірі переходу $з$ однієї області в іншу змінюється. Іншими словами, цей факт можна пояснити еволюцією максимуму градієнта температури та напружень, що веде до часткового захоплення та перерозподілу атомів індію.

Розрахований вище коефіцієнт масопереносу In в $\mathrm{CdTe}$ за порядком величини набагато перевищує коефіцієнти концентраційної дифузії домішок при високих $T$ у напівпровідниках (при звичайних умовах відпалу при дифузійному методі введення домішки) і співмірний з коефіцієнтом самодифузії в більшості рідких металів $\sim 10^{-4}-10^{-6} \mathrm{~cm}^{2} / \mathrm{c}$ та 3 коефіцієнтом дифузї Аg в СdТе при ІЛО - $(3,97-7,2) \cdot 10^{-6} \mathrm{~cm}^{2} / \mathrm{c}$ при $E=20$ та 30 Дж $/ \mathrm{cm}^{2}, \tau_{p}=3$ мс [6]. Там же отримано осцилюючий розподіл домішки In в $\mathrm{CdSb}$ до 75 мкм при $E=14$ Дж/ см$^{2}$. У [13] коефіцієнт масопереносу в залізі при ІЛО при $E_{S}=240$ мДж і $\tau_{p}=30$ нс, $n=10$ імпульсів, дорівнюе $1,6 \cdot 10^{-2} \mathrm{~cm}^{2} /$ с. При $I=$ $10^{7} \mathrm{~B}$ т $/ \mathrm{cm}^{2}$ в залізі $D=3 \cdot 10^{-5} \mathrm{~cm}^{2} /$ с [12], в [10] вказано, що в нікелі при ІЛО $D=(1,2-11,5) \cdot 10^{-5} \mathrm{~cm}^{2} / \mathrm{c}$, а при $E_{S}=5$ Дж і $\tau_{p}=50$ нс $(n=5-20) D^{55,59} \mathrm{Fe}$ в Fe дорівнює $(0,33-0,61) \cdot 10^{-2} \mathrm{~cm}^{2} / \mathrm{c}, D^{95} \mathrm{Nb}$ в Fе дорівнює $(1,12-3,12) \cdot 10^{-2} \mathrm{~cm}^{2} /$ с. Коефіцієнт $D^{137} \mathrm{Cs}$ в Fе дорівнює $(2,4-6,7) \cdot 10^{-5} \mathrm{~cm}^{2} /$ с при $E_{S}=5$ Дж і $\tau_{p}=50$ нс [23]. Дані величини загалом співмірні з нашими значеннями $D$. В роботах $[24,25]$ виявлено, що $D$ атомів міді в нікелі при $I=10^{9}-10^{10}$ Вт $/ \mathrm{cm}^{2}$ і $\tau_{p}=30 \mathrm{нс}$ дорівнює $100 \mathrm{~cm}^{2} / \mathrm{c}$.

Раніше у нашій роботі [7] показано, що процес формування та поширення ударної хвилі і механізм одної концентраційної дифузії не є безпосередніми або домінуючими механізмами процесу масопереносу індію в CdTe при наносекундному ІЛО. У роботі [7] розраховано температуру нагріву поверхні структури In$\mathrm{CdTe}$ і показано, що дифузійні процеси відбуваються у твердій фазі СdTe. Оскільки при $E=100$ мДж/ см $^{2}$ (оптимальний режим опромінення для забезпечення легування) максимальна температура плівки індію товщиною $h=400$ нм дорівнює $220^{\circ} \mathrm{C}(R=0,8)$ i $440{ }^{\circ} \mathrm{C}$ (для $R=0,6$ ). При $h=30$ нм $T=510{ }^{\circ} \mathrm{C}$ $(R=0,8)$ i $1020{ }^{\circ} \mathrm{C}(R=0,6)$, що більше температури плавлення In $-157^{\circ} \mathrm{C}$, але менше температури плавлення $\mathrm{CdTe}-1067{ }^{\circ} \mathrm{C}$.

Ударна деформація і, відповідно, генерація імпульсу стиску при наносекундному лазерному опроміненні In-CdTе відбувається за рахунок:

1. Дуже швидкого, за 20 нс, нагріву (термоудар) i відповідно деформації, швидкість деформації $\dot{\varepsilon}_{z z}=$ $\frac{\varepsilon_{z z}}{\tau_{p}}=\frac{1+\nu}{1-\nu} \frac{\alpha_{T} \Delta T}{\tau_{p}}[10,26]$. При ІЛО до $\Delta T=500-$ $1000{ }^{\circ} \mathrm{C}$ для індію $(\nu=0,46) \dot{\varepsilon}_{z z} \approx(2-4) \cdot 10^{6} \mathrm{c}^{-1}$, для CdTe $\dot{\varepsilon}_{z z} \approx(2,5-5,6) \cdot 10^{5} \mathrm{c}^{-1}$.

2. Швидкого (ударного) фазового переходу тверде тіло-рідина. У загальному випадку $\dot{\varepsilon}=\frac{\Delta h / h_{0}}{\tau_{p}}=$ $\frac{\sqrt[1 / 3]{\Delta V / V_{0}}}{\tau_{p}}[10,15,16], \Delta h-$ зміна лінійного розміру, $\Delta V$ - приріст об'єму при плавленні, $h_{0}$ - початковий розмір приповерхневого шару об'єму $V_{0}$ на глибину дифузії тепла. $\Delta V / V_{0}$ для In дорівнює $2,5 \%$, по $\Delta h$ це $1,36 \%$. Тоді $\dot{\varepsilon}=0,0136 / 20 \mathrm{нс}=6,8 \cdot 10^{5} \mathrm{c}^{-1}$ і більше, оскільки плівка індію нагрівається вище $T$ плавленНЯ.

У роботі [27] показано, що процес швидкого збільшення об'єму зразка при протікаючому за вибуховою кінетикою $\gamma \rightarrow \alpha$-перетворенні сплаву $\mathrm{Fe}-\mathrm{Ni}$ при азотній та гелієвій температурах (ФП 2-го роду) приводить до масопереносу на більшу глибину (до 30 мкм) за час протікання ФП; при цьому експериментально спостерігається значне зростання глибини проникнення радіоактивних ізотопів при одночасній дії деформації і ФП 2-го роду за рахунок швидкого охолодження.

3. Швидкого випаровування з поверхні i, відповідно, генерації тиску віддачі від нерівноважних парів.

4. Оптичного пробою в парах і плазмоутворення (задньою ділянкою лазерного імпульсу) - відбувається виникнення і різке розширення плазми при поглинанні випромінювання, іонізації та пробою. Різке нагрі- 
вання парів і, відповідно, розширення хмари гарячої плазми над поверхнею зразка при світлодетонації при імпульсному лазерному плазмоутворенні також збуджує імпульс значного тиску віддачі.

Дані чотири механізми генерації тиску спільно (інтегрально) і спричиняють бародифузію за рахунок сумарного тиску $P=P_{T}+P_{\text {sol.-liq }}+P_{\text {pairs }}+P_{\text {det }}$. Імовірно, малість розрахованої теоретично швидкості руху атомів In під дією сили $F_{P}(3)$ у порівнянні з експериментально отриманою пояснюється врахуванням тільки першого доданка $P_{T}$.

Підсумовуючи сказане вище, проникнення атомів індію в CdTe якісно можна пояснити таким способом. При наносекундному IЛО In-CdTe за рахунок швидкого (фактично ударного $-\dot{\varepsilon}>10^{5} \mathrm{c}^{-1}$ ) впливу швидкість наростання температури та тиску, а також тиск віддачі при деформації, фазовому переході в In, при генерації парів і плазми з ударними швидкостями наростання настільки великі, що з'являється імпульс стиску зі значним градієнтом напружень. Сумарний імпульс поширюється углиб і стимулює інтенсивну бародифузію In в CdTe. При цьому експериментально виявлене зростання величини $D$ з відстанню узгоджується з фактом збільшення рухливості атомів із глибиною $[10,16,21]$, а великі значення $D \in$ наслідком специфіки масопереносу в умовах імпульсного динамічного впливу, коли коефіцієнт масопереносу атомів сильно зростає в напрямку поширення фронту імпульсу деформації.

Атоми індію (переважно міжвузловинні, за раху-

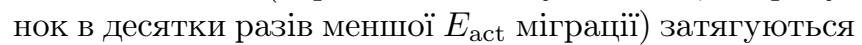
фронтом та градієнтом $P$ імпульсу деформації і переносяться на відстань, що визначається часом ІЛО та релаксації термонапружень. Інтенсивна структурна релаксація за рахунок процесів термопластичності відбувається у плівці індію, оскільки межа пластичності CdTe приблизно у 25 разів більша за межу пластичності In.

Відзначимо, що дані результати можуть бути застосовані до більшості структур плівка-напівнескінченне тверде тіло, особливо плівка металу-напівпровідник для імпульсного твердофазного легування та формування випрямляючих та омічних контактів при виготовленні приладів фото- та оптоелектроніки тощо.

\section{4. Висновки}

Встановлено, що домінуючим механізмом масопереносу при наносекундному лазерному твердофазному легуванні CdTе індієм є бародифузія. Відповідно від- носно глибоке та швидке проникнення атомів індію в CdTe при наносекундному лазерному опроміненні структури In-CdTe при енергіях лазерного імпульсу до плавлення CdTe зумовлене значними градієнтами пружних напружень, що виникають за рахунок швидких процесів нагрівання, плавлення, паро- і плазмоутворення з "ударними" швидкостями протікання. Тому при твердофазному імпульсному лазерному легуванні $\mathrm{CdTe}$ для формування різкого $p-n$-переходу на малій глибині під час створення детекторів доцільним є забезпечення великих і різких градієнтів тиску, а не нагрів; наприклад, шляхом опромінення структури у прозорій рідині або матеріалі (затиснута зовнішня грань).

Визначено коефіцієнти масопереносу індію в CdTe y різних областях при наносекундному опроміненні ексимерним лазером структури In-CdTe 3 товщиною плівки In 30 нм з боку металу при $E=100$ мДж/ $\mathrm{cm}^{2}: D_{0}=1,1 \cdot 10^{-6} \mathrm{~cm}^{2} / \mathrm{c}, D_{1}=3,9 \cdot 10^{-6} \mathrm{~cm}^{2} / \mathrm{c}$, $D_{2}=1,46 \cdot 10^{-5} \mathrm{~cm}^{2} / \mathrm{c}, D_{3}=5,2 \cdot 10^{-5} \mathrm{~cm}^{2} / \mathrm{c}$. При цьому встановлено, що коефіцієнт масопереносу атомів In в CdTe залежить від відстані від поверхні CdTe i зростає, що пов'язано зі зміною з часом неоднорідної деформації кристалічної гратки у процесі дифузії індію.

Встановлено, що середня дрейфова швидкість переміщення атомів In в CdTe при наносекундному лазерному опроміненні структури In-CdTe з товщиною плівки In 30 нм при $E=100$ мДж/см ${ }^{2}$ становить за різними оцінками одиниці-десятки сантиметрів за секунду.

Роботу виконано при фінансовій підтримці Державного фонду фундаментальних досліджень України, проект № $\Phi$ 29.1/013 та 7-ї Рамкової програми ЄС (грант № 218000 "COCAE").

1. V.A. Gnatyuk, T. Aoki, and Y. Hatanaka, Appl. Phys. Lett. 88, 242111 (2006).

2. О.І. Власенко, В.А. Гнатюк, С.М. Левицький, Т. Aoki, Патент України на корисну модель № 41216. Офіційний бюлетень. № 9 (2009).

3. А.Ю. Бончик, С.Г. Кияк, Г.Н. Михайлова, А.В. Похмурская, Г.В. Савицкий, Квантовая электроника 22, 1 (1995).

4. K.К. Джаманбалин, А.Г. Дмитриев, ФТП 24, 11 (1990).

5. Н.К. Зеленина, О.А. Матвеев, Письма в ЖТФ 24, 11 (1998).

ISSN 2071-0194. Укр. фіз. журн. 2011. Т. 56, №2 
6. И.М. Будзуляк, О.И. Данилович, Н.И. Збыковская, И.В. Оманчуковская, О.Э. Панчук, Изв. АН СССР. Серия физическая 49, 4 (1985).

7. В.П. Велещук, А. Байдуллаева, А.И. Власенко, В.А. Гнатюк, Б.К. Даулетмуратов, С.Н. Левицкий, О.В. Ляшенко, Т. Aoki, ФТП 52, 3 (2010).

8. В.П. Воронков, Г.А. Гурченок, ФТП 24, 10 (1990).

9. Дж. Маннинг, Кинетика дифбузии атомов в кристалле (Мир, Москва, 1971).

10. Д.С. Герцрикен, В.Ф. Мазанко, В.М. Тышкевич, В.М. Фальченко, Массоперенос в металлах при низких температурах в условиях внешних воздействий (РИО ИМФ, Киев, 1999).

11. Д.С. Герцрикен, В.Ф. Мазанко, В.М. Фальченко, Импульсная обработка и массоперенос в металлах при низких температурах (Наукова Думка, Киев, 1991).

12. М.Е. Гуревич, А.Ф. Журавлев, Л.Н. Лариков, В.Г. Новицкий, А.Е. Погорелов, Металлофизика 3, 3 (1981)

13. М.Е. Гуревич, Л.Н. Лариков, В.Ф. Мазанко, А.Е. Погорелов, В.М. Фальченко, ФиХОМ №2 (1977).

14. Л.Н. Лариков, В.Ф. Мазанко, А.И. Носарь, В.М. Фальченко, УФЖ 22, 9 (1977).

15. В.М. Миронов, В.Ф. Мазанко, Д.С. Герцрикен, А.В. Филатов, Массоперенос и фазообразование в металлах при импульсных воздействиях (Самарский университет, Самара, 2001).

16. В.М. Миронов, О.А. Миронова, Л.А. Митлина, Д.С. Герцрикен, А.И. Игнатенко, ФиХОМ №4 (2006).

17. Г.А. Сукач, ФТП 31, 6 (1997).

18. В.Б. Фикс, Ионная проводимость в металлах и полупроводниках (электроперенос) (Наука, Москва, 1969).

19. Б.М. Могилевский, А.Ф. Чудновский, Теплопроводность полупроводников (Наука, Москва, 1972).

20. А.Н. Бекренев, Г.Н. Эпштейн, Последеформационные процессы высокоскоростного нагружения (Металлургия, Москва, 1992).

21. В.А. Путилин, А.М. Штеренберг, А.В. Камашев, А.И. Крестелев, Вестник Самарского гос. техн. унивта. Сер. физ.-мат. науки № 9 (2000).

22. Я.Г. Пановко, Основы прикладной теории колебаний и удара (Либроком, Москва, 2010).

23. В.Ф. Мазанко, А.Е. Погорелов, Металлофизика 6, 4 (1984).

24. В.А. Путилин, А.М. Штеренберг, Вестник Самарского гос. техн. унив-та. Сер. физ.-мат. науки № 27 (2004).

25. А.Н. Бекренев, А.В. Камашев, В.А. Путилин, Письма в ЖТФ 19, 13 (1993).
26. A.E. Pogorelov, K.P. Ryaboshapka, and A.F. Zhuravlyov, Journal of Appl. Phys. 92, 10 (2002).

27. В.М. Миронов, Т.Ф. Миронова, Ю.Н. Коваль, Д.С. Герцрикен, В.В. Алексеева, Вестник СамГУ, Естественнонаучная серия №3 (2006).

Одержано 17.11.10

\section{МЕХАНИЗМЫ МАССОПЕРЕНОСА ИНДИЯ В СdTe ПРИ ДЕЙСТВИИ НАНОСЕКУНДНЫХ ЛАЗЕРНЫХ ИМПУЛЬСОВ}

А. Байдуллаева, В.П. Велещук, А.И. Власенко, В.А. Гнатюк, Б.К. Даулетмуратов, С.Н. Левицкий, Т. Аоки

$\mathrm{P}$ е з ю м е

Рассмотрены механизмы импульсного лазерного твердофазного легирования СdТе индием при создании диодных структур для детекторов рентгеновского и гамма-излучения. Показано, что массоперенос индия в CdTе при наносекундном лазерном облучении структуры In-CdTe до порога плавления $\mathrm{CdTe}$ происходит по механизму бародиффузии - вследствие значительного градиента напряжений. Рассчитаны коэффициенты массопереноса индия и оценена средняя дрейфовая скорость перемещения атомов In в CdTe при облучении наносекундным импульсом эксимерного лазера структуры In-CdTe с толщиной пленки In 30 нм при оптимальном для легирования значении плотности энергии $E=100$ мДж/ $\mathrm{cm}^{2}$.

\section{MECHANISMS OF MASS TRANSFER OF INDIUM IN CdTe} UNDER NANOSECOND LASER IRRADIATION

A. Baidullaeva ${ }^{1}$, V.P. Veleschuk ${ }^{1}$, A.I. Vlasenko ${ }^{1}$, V.A. Gnatyuk ${ }^{1}$, B.K. Dauletmuratov ${ }^{1}$, S.N. Levitskii ${ }^{1}$, T. Aoki ${ }^{2}$

${ }^{1}$ V. Lashkaryov Institute of Semiconductor Physics,

Nat. Acad. Sci. of Ukraine

(41, Nauky Ave., Kyiv 03028, Ukraine;

e-mail:vvvit@ukr.net),

${ }^{2}$ Research Institute of Electronics, Shizuoka University

(3-5-1 Johoku, Hamamatsu 432-8011, Japan)

$\mathrm{S} \mathrm{u} \mathrm{m} \mathrm{m} \mathrm{a} \mathrm{r} \mathrm{y}$

The mechanisms of pulsed laser solid-phase doping of CdTe with indium to produce diode structures for X-ray and gamma radiation detectors are considered. It is shown that the indium mass transfer in CdTe under nanosecond laser irradiation of the InCdTe structure below the melting threshold of CdTe takes place by the barodiffusion mechanism due to a considerable stress gradient. We have calculated the mass transfer coefficients of indium and estimated the mean drift velocity of indium atoms in CdTe under irradiation of the In-CdTe structure with the 30-nm-thick In film by a nanosecond excimer laser pulse at $E=100 \mathrm{~mJ} / \mathrm{cm}^{2}$ being the optimal energy density for the doping. 